\title{
NOTES AND DISCUSSION.
}

\section{Ibn Had, the Mohammedan Mystic, and the Jews of Damascus.}

Is the following notice it is my object to add a few items to what is already known concerning the manner in which the Moreh Nebhûhhim spread among the circle of Mohammedan theologians. The biographical sketch which I now submit of a Mohammedan mystic of the thirteenth century affords, moreover, an insight mnto the intimate relations which subsisted beiween the Mohammedans and the Jewish quarter in Damascus, and, judged from this point of riew alone, should be a subject of interest to a student of social history.

The full name of this Mystic, of Andalusian descent, is AlHasan ibn 'Adud al-daulu ibn Hûd al-Gudântî. As the name implies, he belonged to the princely family of the Bunut $H \hat{u} d$, his uncle, on his father's side, being Al-Mutawakkil 'alâ Allâh-one of those Andalusian kinglets who, after the eleventh century, distributed themselves over the remnants of that territory which once formed the mighty Western Caliphate.

Learning was not foreign to this princely family; and it is just in this connection that an interest attaches to the information given by Steinschneider ${ }^{1}$ that a work by Mu'tamin ibn Hûd, Prince of Saragossa, formed the subject of study of Maimonides, with Ibn 'Aknîn.

The father of our Hasan ibn Hûd occupied, as we shall observe, a high position in the State. That of the son, named for short, Abû 'Alî ibn Hûd, was far less brilliant. He was, however, not the only prince who denied himself the worldly pomp of his maternal inheritance, and adopted the mode of life of an ascetic.

The accompanying biographical notice is taken from the work Fawât al-wafajât, written by an Aleppo author, named Mubammed ibn Shâkir al Kutubî (died 1363). The work itself was intended as a sort of aftermath in relation to Ibn Challikân's celebrated and learned Biographical Dictionary, rendered accessible by De Slane's English version to those unacquainted with Oriental languages.

The Arabic text which I have used for my translation is con-

${ }^{1}$ Hebräische Bibliographie, XIII. (1873), p. 40 ; XIV. (1874), p. 38. 
tained in the second edition of Kutubî (Bûlâk, 1299 Higra), Vol. II., pp. 127, 128.

The Scheikh Shams al-dîn" relates as follows :--" The Scheikh and great ascetic, Abû 'Alî ibn Hûd al-Mursî, one of the great authorities on monistic Sufiism (al-tasawwuf alâ tarîkat al-wahdat), was born in the year 633 of the Hegira (=1235-6), at Murcia, of which city his father was the governor. To an extraordinary degree he yielded himself up to ascetic habits, and retired from the world, subjecting himself to the drunkenness (ecstasy of mysticism), which lifted him out of himself, and divested him of his very nature. He devoted himself to medicine, philosophy, and the Ascetic Poems of the School of the Sufis, and blended the knowledge of these subjects together. He undertook the pilgrimage to Mekka, travelled through Yemen, and came to Syria. His dignified bearing was such as to inspire reverence : a hoary man of gentle demeanour, possessed of much knowledge, who had many disciples and adherents. Upon his head he wore a skull cap, which was not concealed by the turban ; upon his person the dress of a monk.

"He was constantly in a deeply contemplative mood, free from the pleasures of the world, in an uniaterrupted state of mourning, living in retirement from all mankind. He was on one occasion seized in a state of intoxication in the Jewish Quarter, and brought before the Prefect of the city, who was favourably disposed towards him and acquitted him. He alleged that the Jews had, out of malice, made him drunk, so that they might circulate this charge against him. He had, it is true, been a source of much evil to them in the past, and had caused quite a host of them (among others $S a^{\prime} \hat{i} d$ and Burakât) to abjure their faith, and to become converted to Islamism. The Scheikh was fond of stewed leg-of-mutton: they invited him to one of their houses and put before him his dainty dish. After be had partaken thereof, he relapsed into his wonted state of absence of mind. Whereupon they had wine brought: he did not disapprove of the presence of this drink. They bade the cup pass round, and he, too, partook, so as to make no exception.

"They now led him, in an intoxicated state, to the public way. The news reached the Wâlî, who rode up to Ibn Hutd, took him upon his own horse, placing him behind himself. The folk gazed after them in astonishment. He (Ibn Hadd), however, cried out from time to time : 'What has befallen Ibn Hind at the drinking of wine?' The $\mathrm{K}$ $(P)$ in the word ' $u k \hat{a} r$, which signfies wine, he pronounced as a soft kâf (Đ).'

\footnotetext{
${ }^{1}$ Cf. Wüstenfeld's Die Geschichtschreiber der Araber und ihre Werke (Göttingen, 1882), p. 176, nr. 415.
} 
"Under his guidance the Jews were wort to occupy themselves with the study of the Kitâb al-dalalat: this is a work upon the principles of their religion by Ra'îs Mûsâ.' The Scheikh Shams al-dîn relates, in the name of our Scheikh 'Imâd al-dîn al Wâsitî, thus :-'I (Al-Wâsitî) came to him (Ibn Hâd) and begged him to undertake to guide me in spiritual things. He asked: "Upon which road? the Mosaic, the Christian, or the Mohammedan?"' At sunrise he turned towards the sun, and crossed himself."

He was a friend of the physician 'Afif 'Imrân, of the Scheikh $S a^{*} \hat{\imath} d$. al.Magrebî, and other learned men. When he died, the Kâdî Badr al-dîn b. Gamấa was the only one who read the burial service over his remains. He was buried on the declivity of Mount Kâsyûn (Damascus) in the year 697 of the Hegira (1297.8.)

The Scheikh Salâh al-dîn al-Safadî (1300-1363) relates the following concerning him :-_"He was once asked by his pupil Saî̀d to show him the Creator of day : whereupon he took him by the hand, climbed on to the roof of a house, and stood half-a-day long, gazing at the sun. He used to walk to the Mosque with a fixed glance, as though he were absent-minded, with up-lifted finger, as it is wont to be raised at confession. Burning coals were often placed in his hand when open, and he wonld close his hand out of mere distraction, recovering his senses only when the coal began to burn, upon which he would throw it away. People were in the habit of digging pits in his way : he was so abstracted and absent-minded that he did not notice them, and fell into these pits."

Budapest.

IGNAZ GOLDZIHER.

The Sign given to King Ahaz (Isaiah vii. 10-17).

IT is not the purpose of this note to discuss the above-mentioned passage in detail, nor to settle the vexed question whether "the damsel" (הָצר? individual, or a general term applying to any woman who should bear a son at the time specified. My object is simply to elucidate the meaning here conveyed by the word תis, "a sign." It was long ago remarked by Gesenius that "a sign" does not necessarily imply anything miraculous, as is shown by such passages as 1 Sam. ii. 27-36. Yet even recent commentators have sometimes found it hard to believe that so ordinary an event as the birth of a child could be

יני וכאן ישתגל אליהוד עליה פי בתאב אלדלאלה והו מצנף פי אצול דינהם 